\title{
A Personal Approach to Patient Care
}




\section{A Personal Approach to Patient Care}

P. J. Hunt

B. Sendell

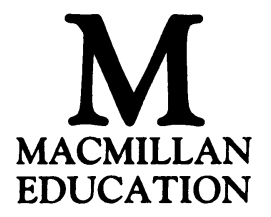




\section{(C) P. J. Hunt and B. Sendell 1987}

All rights reserved. No reproduction, copy or transmission of this publication may be made without written permission.

No paragraph of this publication may be reproduced, copied or transmitted save with written permission or in accordance with the provisions of the Copyright Act 1956 (as amended).

Any person who does any unauthorised act in relation to this publication may be liable to criminal prosecution and civil claims for damages.

First published 1987

Published by

MACMILLAN EDUCATION LTD

Houndmills, Basingstoke, Hampshire RG21 2XS

and London

Companies and representatives

throughout the world

Typeset and designed by

Oxprint Ltd., Oxford

British Library Cataloguing in Publication Data

Hunt, Patricia

A personal approach to patient care.

1. Nursing

I. Title II. Sendell, Bernice

$610.73 \quad$ RT41

ISBN 978-1-349-08564-4 ISBN 978-1-349-08562-0 (eBook)

DOI 10.1007/978-1-349-08562-0

\section{To the patients of the reader}




\section{Contents}

Foreword vi

Preface vii

Acknowledgements viii

$\begin{array}{lll}\text { Section } 1 & \text { Needs } & 1\end{array}$

1 Identification of Needs 3

2 Differences in Individuals 10

Section 2 The Patient 41

$3 \quad$ Breathing 42

$4 \quad$ Eating and Drinking 76

5 Eliminating 110

$6 \quad$ Sleeping and Resting 156

7 Multiple Living Activities 184

$\begin{array}{lll}\text { Section } 3 & \text { The Nurse } & 225\end{array}$

$8 \quad$ The Roles of the Nurse 226

Postscript: Rule of Conduct 235 


\section{Foreword}

The diversity of nursing and the increasing number of specialist groups it contains often makes for confusion in observers, its own practitioners and in aspiring members of the profession. This book sets out a concept of basic care which underpins the wide variety of nursing activities. It provides a critical framework which enables the nurse to adapt this care to meet specific individual needs. In so doing, it provides not only a setting within which learner and practitioner alike can develop and extend their professional practice, but it also demonstrates the underlying principles of care which are the keystone to the profession of nursing.

M. W. Watson, BSc, SRN, SCM Director of Nurse Education Bristol and Weston School of Nursing 


\section{Preface}

We have great pleasure in introducing this nursing text which we hope will be useful and give opportunity for discussion to all nurses and nursing students. We have divided the book into three major sections. The first section gives guidance as to how people differ in response to growth, development, ageing, temperament, social and cultural influences and individual mental and physical capacity. We identify four major categories of needs and give examples of how these may be satisfied.

In the second section we have used Virginia Henderson's components of basic nursing and have looked at functions that require assistance. Each of the five chapters gives references for revision of normal physiology, then consideration is given to the social and psychological factors affecting the chosen living activity. This is followed by a patient history with guidance for assessing the patient's needs, choosing priorities in nursing care and setting short- and long-term goals. At the end of each chapter is a selection of further medical and surgical conditions which may affect living activities, with further reading of selected aspects of pharmacology, physiotherapy and nursing procedures.

The third section considers the multiple roles of the nurse and asks some pertinent questions which could be used for self-evaluation and further activity.

Throughout the complete text the emphasis is on encouraging the reader to participate and in so doing develop a systematic way of assessing, planning and evaluating care.

\section{A NOTE TO THE READER}

We would like to emphasise that each patient regardless of age, temperament or social/cultural background is first and foremost an individual. There can be no substitute for reaching an understanding of the individual patient. This book can only be a very general guide which offers some clues to help you towards that understanding.

A comment from a patient:

'What kind of people do they think we are?' 


\section{Acknowledgements}

The authors would like to extend their thanks to the following people: Wendy Watson, Director of Nurse Education, Bristol and Weston School of Nursing, for her understanding support; Alice Henley for her versatility and willingness in typing our manuscript; Shirley Stephen and Anne Lawrence, Librarians, and their supporting staff at the Bristol and Weston School of Nursing for their assistance; Elizabeth Horne, previously Nursing Editor at Macmillan Press, for continuing encouragement; Anne Betts for reading our efforts and giving constructive criticism; and all the students and staff who have provided feedback prior to publication. 